\title{
EFEKTIFITAS PENGGUNAAN ANALISIS TEKNIKAL STOCHASTIC OSCILLATOR DAN MOVING AVERAGE CONVERGENCE-DIVERGENCE (MACD) PADA PERDAGANGAN SAHAM-SAHAM JAKARTA ISLAMIC INDEX (JII) DI BURSA EFEK INDONESIA
}

\author{
Adi Prabhata \\ Akademi Akuntansi YKPN Yogyakarta \\ e-mail: adi.prabhata@aaykpn.ac.id
}

The study was conducted to measure the effectiveness of using two tools of technical analysis, namely the Stochastic Oscillator and Moving Average Convergence Divergence (MACD) in 10 stocks of the Jakarta Islamic Index (JII) in Indonesia Stock Exchange within three years, 2008, 2009, and of 2010. The conclusions are that in that year, the use of the Stochastic Oscillator generates signals true on average for every 47.1 times as many shares or $72.76 \%$ and false signals as much as 18.3 times, or $27.24 \%$. The use of true MACD signal produced 14.10 times $(61.81 \%)$, false signal 8.7 times (38.19\%). These results indicate that the use of technical analysis tools that can provide a return on stocks JII. It was not statistically proven that the Stochastic Oscillator gives better results than the MACD, or vice versa. Furthermore, although these tools provide benefits, but not proven that these tools can provide abnormal returns for its users. This study also implies that the capital market in Indonesia, especially stocks that meet the criteria of Islamic stock market does not show any efficiency.

Keywords: Jakarta Islamic Index (JII), Analisis teknikal, Stochastic Oscillator, Moving Average Convergence-Divergence (MACD).

\section{PENDAHULUAN}

Yang harus dilakukan oleh seorang investor untuk mendapatkan keuntungan optimal di Pasar Modal, sangat sederhana, yaitu membeli efek pada saat harganya "murah" dan menjualnya kembali pada saat harga "mahal". Masalahnya menjadi tidak lagi sederhana karena momentum harga "murah" dan "mahal" tersebut sangat sulit dipastikan sebab berhubungan dengan sesuatu yang akan terjadi di masa mendatang sehingga berada di luar kemampuan manusia. Sebagai contoh, pada saat ini harga per lembar saham " $X$ " adalah Rp1.000,- .Pada saat ini pula tidak ada seorangpun yang dapat memastikan apakah esok hari harga saham tersebut akan naik atau turun, dan jika naik atau turun menjadi harga berapa. Orang hanya dapat memprediksi, memprakirakan, atau meramal menggunakan berbagai macam cara, alat, dan metoda.

Secara garis besar alat-alat analisis dapat dikelompokkan menjadi 2 kelompok besar. (1) Analisis Fundamental yaitu metode analisis yang didasarkan pada fundamental ekonomi suatu perusahaan. (2) Analisis Teknikal, yaitu analisis terhadap pergerakan harga atau pengamatan terhadap pergerakan harga yang terjadi detik demi detik, hari demi hari dalam jangka waktu tertentu yang ditampilkan dalam bentuk chart/diagram/grafik (Ang, 1997).

Berbagai penelitian telah dilakukan yang mengindikasikan bahwa penggunaan analisis teknikal dapat membantu investor untuk memperoleh abnormal return, yaitu selisih antara penghasilan riil dengan penghasilan yang diharapkan, atau dengan kata lain penghasilan yang lebih tinggi dibanding dengan penghasilan pada 
umumnya. Park dan Irwin (2004) berhasil merangkum 92 penelitian modern tentang analisis teknikal sejak tahun 1960-an, di mana 58 diantaranya menghasilkan kesimpulan positif, 24 negatif, dan sisanya, yaitu 10 penelitian menghasilkan kesimpulan campuran. Brock, et. al (1992), melakukan penelitian pada beberapa macam teknik moving average dan menyimpulkan bahwa alat-alat tersebut dapat digunakan untuk memprediksi harga saham. Shundar dan Kakani (2006) dan Naha dan Zaidi (2004) menemukan bahwa penggunaan Simple Moving Average (SMA) dan Displaced Moving Average (DMA), serta alat-alat analisis teknikal lain seperti Moving Average Convergence-Divergence (MACD), Bolinger Bands dan Relative Strength Index (RSI) di pasar modal India cukup sukses menghasilkan keuntungan.

Sungguhpun demikian, tidak semua orang mendukung penggunaan analisis teknikal untuk melakukan analisis investasi di pasar modal. Menurut Fama (1970), tidak ada seorangpun yang dapat memperoleh abnormal return karena adanya efficient market hypothesis (EMH). Fama membagi bentuk efisiensi pasar menjadi 3, yaitu: (1) efisiensi pasar bentuk lemah (weak form) sehingga selaras dengan Random Walk Theory, (2) efisiensi pasar bentuk setengah kuat (semistrong form), dan (3) efisiensi pasar bentuk kuat (strong form). Yang membedakan bentuk efisiensi pasar tersebut adalah jenis, bentuk, dan masa informasi yang diterima oleh investor, yaitu: informasi masa lalu, informasi sekarang, dan informasi privat/tidak dipublikasikan. Hipotesis pasar efisien bentuk lemah menyatakan bahwa harga saham telah merefleksikan seluruh informasi masa lalu atau informasi historis. Bentuk setengah kuat menyatakan bahwa seluruh informasi yang telah terpublikasi akan terefleksi pada harga saham. Sedang bentuk kuat menyatakan bahwa harga saham merefleksikan seluruh informasi termasuk pula informasi yang tidak dipublikasikan. Penganut Teori EMH berpendapat bahwa berinvestasi di saham menggunakan alatalat analisis teknikal tidak akan menghasilkan perbedaan return yang signifikan dibanding dengan menggunakan cara berinvestasi di sekuritas yang paling naif dan sederhana, yaitu buy and hold.

Kontroversi antara dua kubu tersebut mengundang berbagai penelitian untuk membuktikan tentang adanya bentuk efisiensi pasar di pasar-pasar modal di seluruh dunia. Marshall et. al (2010) meneliti tentang penggunaan analisis teknikal di dunia menyimpulkan pasar modal di negara-negara berkembang tidak mengikuti teori random walk. Kim dan Shamsuddin (2007) menyimpulkan bahwa pasar modal Indonesia, Malaysia dan Filipina sama sekali tidak mengindikasikan adanya bentuk efisiensi pasar.

Hasil penelitian yang sangat beragam tersebut menarik minat penulis untuk melakukan penelitian tentang penggunaan analisis teknikal khusus di bursa efek Indonesia. Apabila pasar modal Indonesia tidak menunjukkan adanya bentuk efisiensi pasar, apakah penggunaan alat analisis teknikal dapat digunakan untuk memperoleh abnormal return?

\section{KAJIAN TEORI DAN PENGEMBANGAN HIPOTESIS}

Keingintahuan para investor akan efektifitas penggunaan alat-alat analisis teknikal banyak mengundang reaksi para peneliti, baik dari kalangan akademisi, maupun praktisi pasar modal. Cukup banyak penelitian yang dilakukan para ahli untuk mencoba menjawab pertanyaan tersebut. Sebagian mendukung penggunaan analisis teknikal untuk memprediksi harga dan sebagian lagi percaya kepada efficient market hypothesis (EMH). Salah satu diantaranya adalah penelitian yang dilakukan oleh Park dan Irwin (2004) yang berhasil merangkum 92 penelitian modern tentang analisis teknikal sejak tahun 1960-an. Dari 92 penelitian yang berhasil dikumpulkan, 58 diantaranya 
menghasilkan kesimpulan positif, 24 negatif, dan sisanya, yaitu 10 penelitian menghasilkan kesimpulan campuran.

Shundar dan Kakani (2006) melakukan penelitian dengan menggunakan Simple Moving Average (SMA) dan Displaced Moving Average (DMA) untuk mengukur efisiensi pasar bentuk lemah di pasar modal India. Indikator tersebut diaplikasikan pada indeks S\&P CNX Nifty, BSE Sensex dan pada beberapa saham individual dalam kurun waktu 15 tahun (19912005). Penelitian tersebut menghasilkan kesimpulan bahwa DMA cukup sukses menghasilkan capital gain. Naha dan Zaidi (2004) melakukan penelitian di pasar modal yang sama menyimpulkan bahwa analisis teknikal memungkinkan untuk diterapkan pada grafik saham yang berumur 5 hingga 10 tahun. Alat-alat analisis teknikal: Moving Average ConvergenceDivergence (MACD), Bolinger Bands dan Relative Strength Index (RSI), dan Exponential Moving Average (EMA) dapat menghasilkan hasil yang positif. Di pasar modal Hongkong, Lam et. al. (2007), melakukan penelitian menggunakan Simple Moving Average (SMA) dan Trading Range Break (TRB) pada indeks Hang Seng dengan data 35 tahun (1972 s.d. 2006). Secara garis besar disimpulkan bahwa penggunaan moving average dapat menghasilkan capital gain yang signifikan. Rata-rata return yang didapat lebih tinggi dibanding dengan rata-rata return di pasar modal USA (Brock et.al, 1992), sedangkan penggunaan TRB tidak menghasilkan return yang signifikan. Penelitian Rubio (2003) menghasilkan kesimpulan bahwa penggunaan analisis teknikal jauh lebih baik dibanding hanya menggunakan strategi "to buy and to maintain" di pasar modal Amerika Serikat dan Spanyol.

Penelitian yang dilakukan oleh Wong et. al (2002) di bursa efek Singapura menggunakan Moving Average (MA) dan Relative Strength Index (RSI). Hasilnya mengindikasikan bahwa alat-alat analisis di atas dapat digunakan untuk men- dapatkan return positif. Terbukti pula bahwa para anggota Singapore Stock Exchange (SES) menghasilkan keuntungan yang tinggi dengan menerapkan indikator teknikal. Temuan ini memberikan jawaban mengapa sebagian besar perusahaan tersebut memiliki trading team sendiri yang sepenuhnya mengandalkan pada analisis teknikal. Meissner et.al. (2002) meneliti saham-saham pada NASDAQ-100 menggunakan MACD dan turunannya yang disebut dengan MACDR2. Penggunaan MACD hanya menghasilkan success rate sebesar 32,73\% selama kurun waktu 10 tahun sementara MACDR2 menghasilkan success rate sebesar 89,39\%. Meissner meyimpulkan bahwa studi ini memberikan bukti-bukti yang bertentangan dengan random walk hypothesis. Lento (2008), mengukur efektifitas penggunaan 9 alat analisis teknikal pada saham-saham S\&P 500 selama 58 tahun, dari Januari 1950 sampai dengan Maret 2008 (14.646 hari observasi) dengan cara membandingkannya dengan metode hold and buy. Hasilnya, Combined Signal Approach (CSA), yaitu alat analisis teknikal yang ditemukan oleh Lento and Gradojevic menghasilkan return yang secara signifikan mengungguli buy and hold. Secara individual, hanya Moving Average Crossover yang dapat mengungguli buy and hold. Tujuh alat lainnya tidak mampu memberikan return yang melebihi return yang didapat melalui buy and hold.

Wong, et. al. (2005) juga melakukan penelitian di 3 pasar modal asia, yaitu China, Hong Kong dan Taiwan. Penelitian ini membandingkan alat-alat analisis teknikal simple moving average, exponential moving average, dual moving average, triple moving average, MACD dan TRIX dengan strategi buy and hold. Hasilnya, kelompok moving average mengungguli buy and hold dan menghasilkan return positif secara signifikan di kelompok pasar modal China (China, Hong Kong, dan Taiwan). Hasil yang sama diperoleh pada masa sebelum dan sesudah krisis 1997. Alat-alat tersebut juga bekerja dengan baik pada berbagai 
kondisi pasar, yaitu bull, bear, maupun campuran (sideways). Hal ini memberikan implikasi bahwa ketiga pasar modal di Cina tersebut tergolong tidak efisien.

\section{Landasan Teori Pasar Modal}

Pasar Modal adalah pertemuan antara pihak yang memiliki kelebihan dana dengan pihak yang membutuhkan dana dengan cara memperjualbelikan sekuritas (Tandelilin, 2010). Dana-dana jangka panjang yang merupakan utang biasanya berbentuk obligasi, sedangkan dana jangka panjang yang merupakan dana modal sendiri biasanya berbentuk saham. Pasar modal mempunyai peran dan manfaat penting dalam perekonomian suatu negara karena menciptakan fasilitas bagi keperluan industri atau investor dalam memenuhi permintaan dan penawaran modal.

\section{Analisis Fundamental}

Analisis Fundamental adalah adalah metode analisis yang didasarkan pada fundamental ekonomi suatu perusahaan. Teknis ini menitikberatkan pada rasio finansial dan kejadian-kejadian yang secara langsung maupun tidak langsung mempengaruhi kinerja keuangan perusahaan. Sebagian pakar berpendapat teknik analisis fundamental lebih cocok untuk membuat keputusan dalam memilih saham perusahaan mana yang dibeli untuk jangka panjang.

Fundamental analysis is a method of forecasting the future price movements of financial instrument based on economic, political, environmental, and other relevant factors and statistics that will affect the basic supply and demand of whatever underlies the financial instrument. (Reuters 1999).

Analisis fundamental dibagi dalam tiga tahapan analisis yaitu analisis ekonomi, analisis industri, dan analisis perusahaan. Dalam analisis fundamental, yang dijadikan dasar perkiraan harga (intrinsic value) adalah faktor-faktor fundamental seperti laporan keuangan, informasi penting lain yang sewaktu-waktu harus diumumkan perusahaan publik dan perkembangan ekonomi makro, mau pun berita dalam bidang-bidang lain seperti politik, sosial, dan lain sebagainya.

\section{Analisis Teknikal}

Analisis teknikal adalah analisis terhadap pergerakan harga atau pengamatan terhadap pergerakan harga yang terjadi detik demi detik, hari demi hari dalam jangka waktu tertentu yang ditampilkan dalam bentuk chart/diagram. Menurut Murphy (1999),

"technical analysis is the study of market action, primarily through the use of charts, for the purpose of forecasting future price trends".

Pring (2002), memberikan definisi yang lebih spesifik:

"The technical approach to investment is essentially a reflection of the idea that prices move in trends that are determined by the changing attitudes of investors toward a variety of economic, monetary, political, and psychological forces. The art of technical analysis, for it is an art, is to identify a trend reversal at a relatively early stage and ride on that trend until the weight of the evidence shows or proves that the trend has reversed."

Ide utama dari analisis teknikal adalah menggunakan data-data pergerakan harga dari waktu yang lalu untuk menentukan kemana harga pergerakan harga selanjutnya. Hal yang terpenting dari analisis teknikal adalah bagaimana analisis tersebut mampu mengenali trend sedini mungkin. Analisis teknikal dilakukan dengan memanfaatkan pola pergerakan indeks atau harga dari masa ke masa. Sejarah pergerakan harga tersebut dapat berupa data setiap sekian detik, 
menit, jam, , minggu, bulan, atau mungkin data tahunan, tergantung pada kebutuhan. Oleh karena itu, para pengguna analisis teknikal percaya bahwa apabila digunakan secara benar, analisis teknikal dapat memberikan tuntunan yang lebih praktis dan cepat sehingga dapat memberikan keuntungan yang lebih optimal. Murphy (1999) juga mengatakan bahwa

"Chartists are cheating, because it is a short cut form of fundamental analysis".

Analisis teknikal digunakan dengan berdasarkan atas 3 asumsi (Eric et al., 2009) yaitu: 1) The market discounts all relevant information. 2) Price moves in trends. 3) History tends to repeat itself. 4) The Market Discounts All Relevant Information.

Analisis teknikal menggunakan asumsi bahwa harga pasar sebuah saham sudah merefleksikan seluruh informasi yang berkaitan dengan fundamental, politik, psikologis atau semua informasi lain yang berdampak pada perubahan harga. Berdasarkan asumsi ini, pengguna analisis teknikal merasa cukup hanya melakukan analisis pergerakan harga tanpa harus melakukan analisis fundamental untuk membuat keputusan investasi. Mereka hanya berkepentingan terhadap perubahan harga dan tidak membutuhkan alasan tentang perubahan harga tersebut. a) Price Moves In Trends. Pada analisis teknikal, konsep pergerakan arah atau trend sangatlah penting. Berdasarkan prinsip ini, harga dipercaya bergerak ke satu arah, yaitu naik, turun, atau menyamping secara konstan. Tren ini akan berkelanjutan hingga pada suatu saat pergerakan harga akan melambat dan memberikan peringatan sebelum berbalik dan bergerak ke arah yang bertentangan. Tugas analisis teknikal adalah mengidentifikasi arah pergerakan harga dan kekuatan tren sedini mungkin (Eric et al., 2009) sehingga investor dapat memanfaatkannya untuk melakukan keputusan investasi. b) History Tends To Repeat Itself. Karena analisis tek- nikal juga menggambarkan faktor psikologi para pelaku pasar misalnya faktorfaktor yang berkaitan dengan perilaku investasinya, maka pergerakan harga di masa lalu dapat dijadikan acuan untuk memprediksi pergerakan harga di masa yang akan datang. Sejarah pergerakan harga ini direkam dalam bentuk grafik. Selama lebih dari 100 tahun grafik pergerakan harga ini telah dipolakan dan hingga kini masih digunakan sebagai acuan untuk memprediksi pergerakan harga.

Dari lebih dari 200 indikator analisis teknikal, Moving Average, atau Rata-rata Bergerak adalah indikator yang paling mudah digunakan dan paling populer (Calginap, et al., 2003). Sayangnya, indikator tersebut hanya berlaku pada kondisi trend yang kuat, baik uptrend maupun downtrend. Pada kondisi pasar yang tidak menentu (choppy), alat analisis ini akan kehilangan kemampuannya (Thorp, 2009). Mengingat bahwa karakteristik pasar saham Indonesia cenderung choppy di mana harga cenderung naik dan turun tidak menentu, maka diperlukan sebuah indikator yang lebih sensitif dan responsif, yaitu indikator-indikator yang dikategorikan ke dalam kelompok oscilator. Para analis teknikal (yang terkenal dengan sebutan "technicians" atau "chartists"), menggunakan oscilator untuk menentukan titik overbought dan oversold, menentukan momentum sebuah sekuritas, dan mengidentifikasi divergence (ketidakselarasan) antara harga dan indikatornya.

Dua buah indikator dalam kelompok oscillator yang mampu menggabungkan keunggulan-keunggulan dari Moving Average sebagai indikator tren dan oscilator adalah Stochastic Oscillator dan Moving Average Convergence Divergence, atau lebih dikenal dengan singkatan MACD. Stochastic Oscillator dikembangkan oleh Jeorge C lane pada tahun 1950-an, sedangkan MACD diciptakan oleh Gerald Appel di tahun 1985. 


\section{Stochastic Oscillator}

Alat ini digunakan untuk mengidentifikasikan munculnya kondisi oversold dan overbought (Achelis, 2003). Oscillator ini dibentuk menggunakan 2 buah garis, yaitu garis $\% \mathrm{~K}$, yaitu grafik yang mengambarkan posisi harga relatif terhadap harga tertinggi dan terendah pada periode tertentu dan garis \% D yang berasal dari perhitungan simple average \% K. Cara menghitung \%K dan \%D dapat dilihat pada Lampiran 1. Stochastic Oscillator mempunyai nilai antara 0 dan 100 . Jika nilai $\% \mathrm{~K}$ sama dengan 0 maka berarti bahwa harga penutupan yang terjadi merupakan harga terendah yang terjadi selama periode pengamatan. Sebaliknya, jika \%K bernilai 100 berarti harga penutupan tersebut merupakan harga tertinggi selama periode pengamatan. Nilai di atas 80 dikategorikan sebagai kondisi overbought, sementara nilai di bawah 20 dikategorikan sebagai kondisi oversold.

\section{Moving Average Convergence-Divergence (MACD)}

Garis MACD berasal dari selisih antara exponential moving average (XMA) 26 periode dan 12 periode (Murphy, 1999 dan Achelis, 2003). Penentuan periode ini dapat diubah sesuai dengan karakteristik efeknya. Garis MACD yang terbentuk kemudian digabungkan dengan sebuah garis yang biasa disebut dengan trigger line, yaitu garis yang berasal dari XMA 9 periode dari MACD. Sejalan dengan waktu, kedua garis ini secara konstan saling berpotongan. Dari pergerakan kedua garis inilah didapatkan indikasi-indikasi pergerakan harga saham serta signal-signal yang berkaitan dengan "time to buy/sell". Pada indikator ini terdapat pula sebuah garis yang terletak di tengah (posisi 0).

Gambar 2 di bawah adalah sebuah contoh bagaimana menggunakan MACD untuk "membaca" saham Bank Niaga Tbk.

\section{Formalisasi Hipotesis}

Berdasarkan tinjauan pustaka atau kerangka pemikiran di atas, maka rumusan hipotesis yang akan diuji kebenarannya, apakah hasil penelitian akan menerima atau menolak hipotesis tersebut, adalah sebagai berikut.

$\mathrm{H}_{1}$ : Pasangan sinyal buy dan sell Stochastic Oscillator menghasilkan capital gain

$\mathrm{H}_{2}$ : Pasangan sinyal buy dan sell MACD menghasilkan capital gain

$\mathrm{H}_{3}$ : Ada perbedaan antara Stochastic Oscillator dan MACD dalam menghasilkan capital gain.

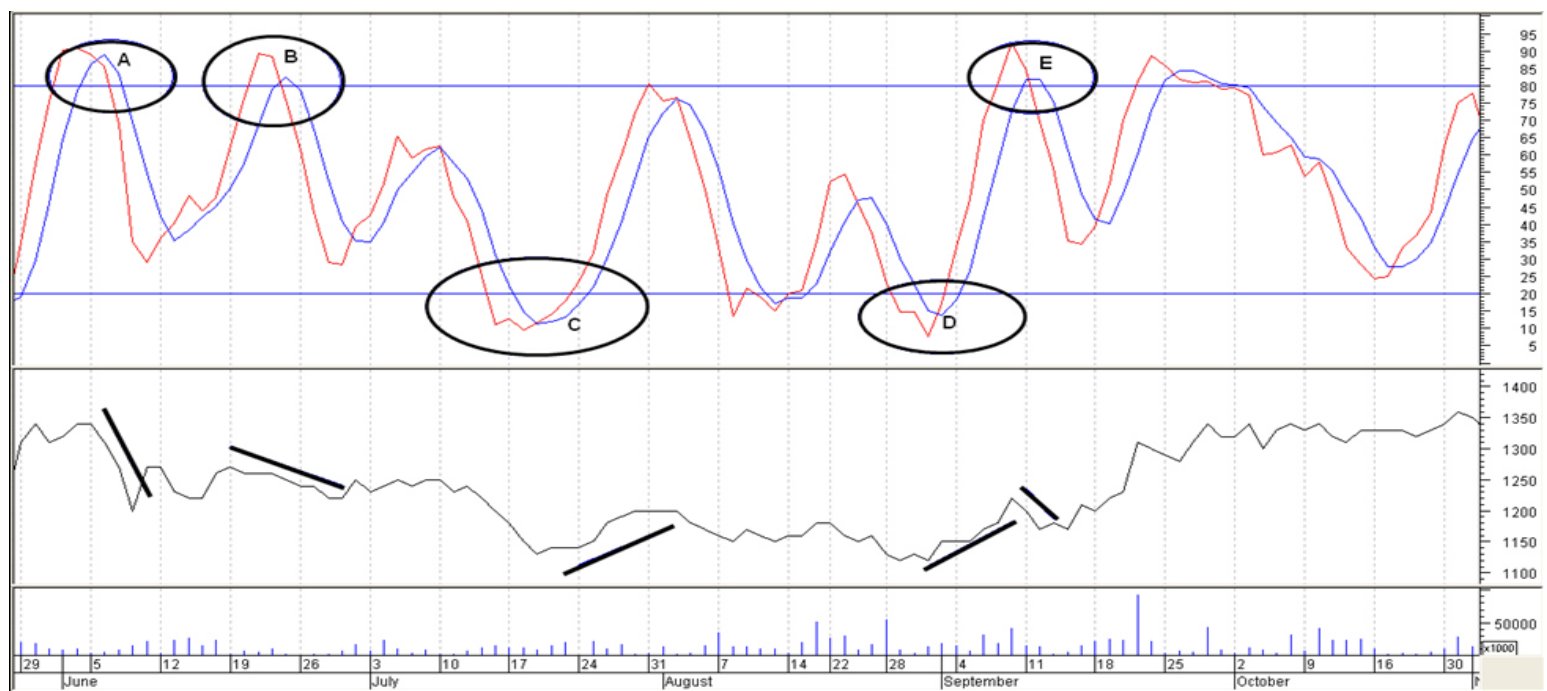

Gambar 1: Stocastic Oscillator 


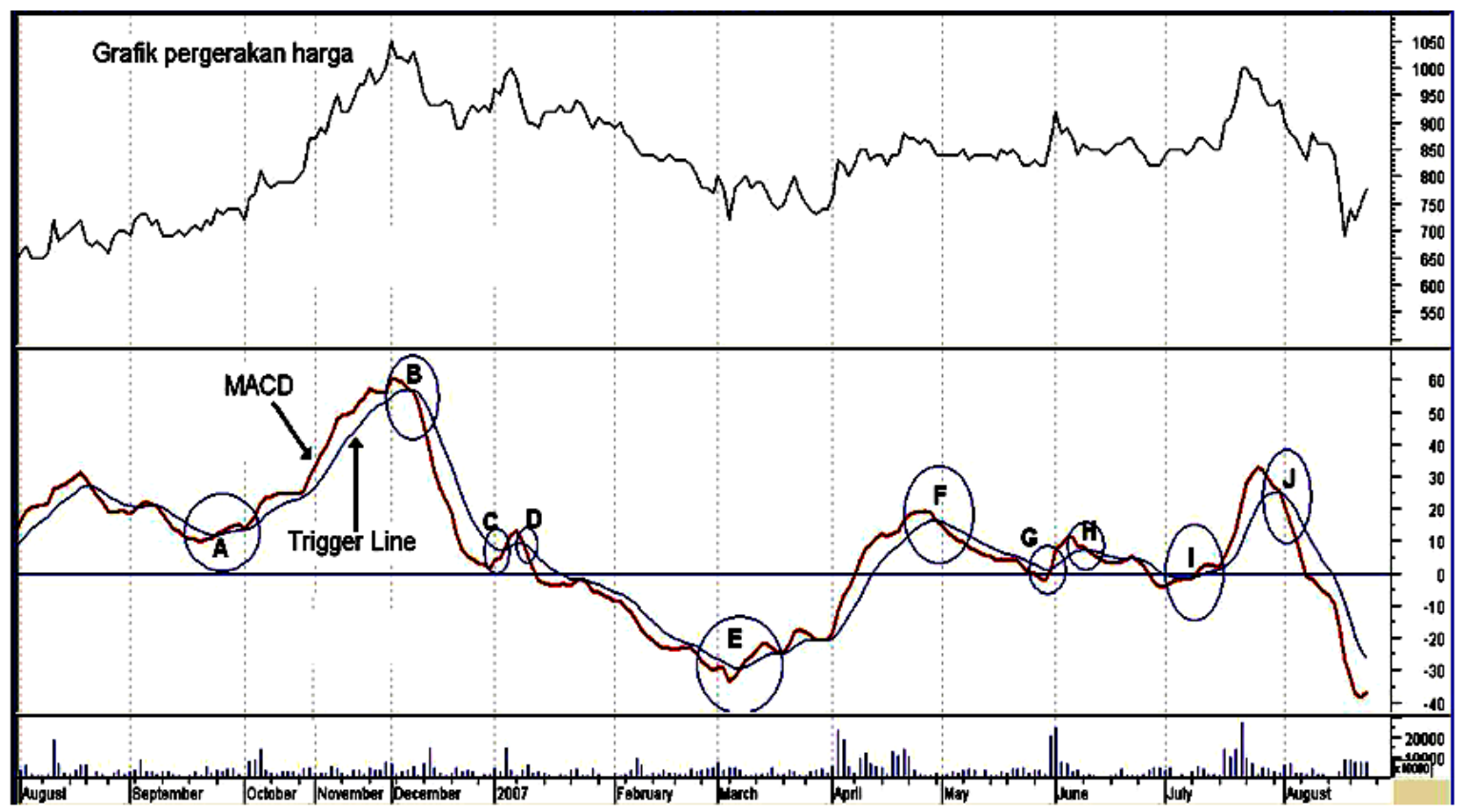

Gambar 2. Moving Average Convergence-Divergence

\section{METODE PENELITIAN}

Populasi dan Penentuan Sampel Penelitian Penelitian ini akan menggunakan data sekunder berupa harga penutupan saham yang terdaftar di Bursa Efek Indonesia. Data diambil sebanyak 3 titik tahun, yaitu tahun 2008, 2009, dan 2010; masing-masing tahun dibagi ke dalam caturwulan $(\mathrm{Cw})$, jaitu Cw1: Januari-April, Cw2: MeiAgustus, Cw3: September-Desember sehingga akan terbentuk 9 kelompok data, yaitu (a) Cw1-2008, (b) Cw2-2008, (c) Cw32008, (d) Cw1-2009, (e) Cw2-2009, (f) Cw32009, (g) Cw1-2010, (h) Cw2-2010, (i) Cw32010.
Jumlah saham yang akan diteliti 10 saham diambil secara acak dalam kelompok indeks Jakarta Islamic Index (JII). JII adalah indeks saham yang terdiri dari 30 saham terbaik yang dipilih dari sahamsaham yang sesuai dengan syariah Islam. Saham-saham tersebut adalah sebagaimana disajikan pada tabel 1. Dengan menggabungkan kelompok periode dengan jumlah saham akan terbentuk sebuah matriks data yang beranggotakan 90 kelompok data yang berasal dari 3 caturwulan per tahun selama 3 tahun untuk 10 jenis saham $(3 \times 3 \times 10)$.

Tabel 1: Daftar emiten

\begin{tabular}{rll}
\hline No & Ticker/ Kode Saham & Nama Perusahaan \\
\hline 1 & AALI & PT Astra Agro Lestari Tbk. \\
2 & ANTM & PT Aneka Tambang (Persero) Tbk. \\
3 & ASII & PT Astra International Tbk. \\
4 & INCO & PT International Nickel Indonesia Tbk. \\
5 & KLBF & PT Kalbe Farma Tbk. \\
6 & LPKR & PT Lippo Karawaci Tbk. \\
7 & SMGR & PT Semen Gresik (Persero) Tbk. \\
8 & TLKM & PT Telekomunikasi Indonesia (Persero) Tbk. \\
9 & UNTR & PT United Tracktors Tbk. \\
10 & UNVR & PT Unilever Indonesia Tbk. \\
\hline
\end{tabular}


Sumber Data dan Teknik Pengumpulan Data

Data diperoleh dari Bursa Efek Indonesia melalui Downloader program Metastock ${ }^{\circledR}$ versi 10.0. Data tersebut kemudian dikonversikan ke format data Excel. Untuk mempermudah pengolahan data, akan dimanfaatkan juga attachment dari Metastock ${ }^{\circledR}$, yaitu Expert Advisor ${ }^{\mathrm{TM}}$, yaitu sebuah program tambahan yang dapat menampilkan sinyal jual dan sinyal beli pada grafik Metastock®.

\section{Definisi dan Pengukuran Variabel Penelitian}

Dengan menggunakan alat analisis Stochastic Oscilator dan MACD, harga penutupan saham terpilih yang menghasilkan sinyal beli dan sinyal jual akan dipasangkan untuk dihitung besaran laba/ruginya. Variabel hasil perhitungan tersebut kemudian dikelompokkan ke dalam masingmasing 90 kelompok, sehingga akan terbentuk $2 \times 90=180$ kelompok variabel. Nilai rata-rata dari masing-masing kelompok kemudian akan dianalisis.

Tabel 2: Daftar Variabel

\begin{tabular}{lll}
\hline Variabel & \multicolumn{2}{l}{ Keterangan } \\
\hline$\overline{\mathrm{x}}_{1}$ & Rerata return menggunakan \\
$\overline{\mathrm{x}}_{2}$ & Stochastic Oscillator \\
\hline
\end{tabular}

MACD

\section{ANALISIS DAN PEMBAHASAN Analisis Diskriptif}

Selama kurun waktu pengujian, yaitu mulai dari 2-1-2008 hingga 30-12-2010 menggunakan 10 buah saham diperoleh hasil bahwa setiap trade, yaitu pasangan buy-sell baik menggunakan metode Stochastic Oscillator maupun MACD akan menghasilkan 3 jenis return, yaitu: return positif (laba), return negatif (rugi), atau return $=0$ (impas). Return positif disebut dengan True Signal karena harga jual lebih tinggi dibanding harga beli, sedangkan return negatif, yaitu harga jual lebih rendah dari harga beli, dan impas (harga jual sama dengan harga beli) disebut sebagai False Signal. Tabel 3 dan 4 di bawah menunjukkan jumlah dan proporsi masing-masing true dan false signal.

Diperoleh hasil bahwa dengan menggunakan Stochastic Oscillator, dalam kurun waktu 3 tahun diperoleh rata-rata $72,76 \%$ true signal yang menghasilkan return positif sebelum biaya transaksi dan $70,87 \%$ true signal setelah memperhitungkan komisi beli dan komisi jual sebesar masing-masing $0,25 \%$ dan pajak $0,10 \%$ untuk setiap saham. Angka itu membuktikan bahwa pasangan sinyal buy-sell yang dihasilkan Stochastic Oscillator lebih sering menghasilkan laba dibanding dengan rugi.

Tabel 3: STOCHASTIC OSCILLATOR: True vs False Signal

\begin{tabular}{clcccccccc}
\hline \multirow{2}{*}{ No } & \multirow{3}{*}{ Saham } & \multicolumn{4}{c}{ True Signal } & \multicolumn{2}{c}{ False Signal } & \multicolumn{4}{c}{ True Signal } & \multicolumn{2}{c}{ False Signal } \\
& & Jml & \% & Jml & \% & Jml & \% & Jml & \% \\
\hline 1 & AALI & 49 & 83,05 & 10 & 16,95 & 46 & 77,97 & 13 & 22,03 \\
2 & ANTM & 31 & 86,11 & 5 & 13,89 & 31 & 86,11 & 5 & 13,89 \\
3 & LPKR & 37 & 63,79 & 21 & 36,21 & 37 & 63,79 & 21 & 36,21 \\
4 & SMGR & 47 & 72,31 & 18 & 27,69 & 46 & 70,77 & 19 & 29,23 \\
5 & TLKM & 49 & 69,01 & 22 & 30,99 & 44 & 61,97 & 27 & 38,03 \\
6 & UNTR & 54 & 76,06 & 17 & 23,94 & 53 & 74,65 & 18 & 25,35 \\
7 & UNVR & 57 & 76,00 & 18 & 24,00 & 57 & 76,00 & 18 & 24,00 \\
8 & ASII & 55 & 77,46 & 16 & 22,54 & 55 & 77,46 & 16 & 22,54 \\
9 & INCO & 52 & 66,67 & 26 & 33,33 & 49 & 62,82 & 29 & 37,18 \\
10 & KLBF & 40 & 57,14 & 30 & 42,86 & 40 & 57,14 & 30 & 42,86 \\
\hline & Rata-rata & 47,10 & 72,76 & 18,30 & 27,24 & 45,80 & 70,87 & 19,60 & 29,13 \\
\hline
\end{tabular}

Tabel 4: MACD: True vs False Signal 


\begin{tabular}{clcccccccc}
\hline & & \multicolumn{4}{c}{ Sebelum Fee } & \multicolumn{5}{c}{ Setelah Fee } \\
No & Saham & \multicolumn{2}{c}{ True Signal } & \multicolumn{2}{c}{ False Signal } & \multicolumn{2}{c}{ True Signal } & \multicolumn{2}{c}{ False Signal } \\
& & Jml & \% & Jml & \% & Jml & $\%$ & Jml & $\%$ \\
\hline 1 & AALI & 14 & 60,87 & 9 & 39,13 & 13 & 56,52 & 10 & 43,48 \\
2 & ANTM & 13 & 56,52 & 10 & 43,48 & 13 & 56,52 & 10 & 43,48 \\
3 & LPKR & 13 & 56,52 & 10 & 43,48 & 13 & 56,52 & 10 & 43,48 \\
4 & SMGR & 16 & 59,26 & 11 & 40,74 & 16 & 59,26 & 11 & 40,74 \\
5 & TLKM & 12 & 63,16 & 7 & 36,84 & 12 & 63,16 & 7 & 36,84 \\
6 & UNTR & 20 & 76,92 & 6 & 23,08 & 20 & 76,92 & 6 & 23,08 \\
7 & UNVR & 15 & 62,50 & 9 & 37,50 & 14 & 58,33 & 10 & 41,67 \\
8 & ASII & 14 & 56,00 & 11 & 44,00 & 13 & 52,00 & 12 & 48,00 \\
9 & INCO & 11 & 57,89 & 8 & 42,11 & 11 & 57,89 & 8 & 42,11 \\
10 & KLBF & 13 & 68,42 & 6 & 31,58 & 13 & 68,42 & 6 & 31,58 \\
& Rata-rata & 14,10 & 61,81 & 8,70 & 38,19 & 13,80 & 60,56 & 9 & 39,44 \\
\hline
\end{tabular}

Dengan menggunakan MACD, dalam kurun waktu 3 tahun diperoleh rata-rata $61,81 \%$ true signal yang menghasilkan return positif sebelum biaya transaksi dan 60,56\% true signal setelah memperhitungkan komisi beli dan komisi jual sebesar masing-masing $0,25 \%$ dan pajak $0,10 \%$ untuk setiap saham. Angka itu membuktikan bahwa pasangan sinyal buysell yang dihasilkan MACD menghasilkan laba lebih sering dibanding dengan rugi.

Dibandingkan dengan MACD, Stochastic Oscillator lebih banyak/sering menghasilkan trading signal, yaitu rata-rata 65,40 kali untuk setiap saham selama kurun waktu 3 tahun, sementara MACD hanya menghasilkan rata-rata 22,8 trading signals. Dengan asumsi setiap tahun tersedia 240 hari transaksi, maka Stochastic Oscillator rata-rata menghasilkan satu signal setiap 11 hari, dan MACD setiap 31,6 hari.

Tabel 5 di bawah menunjukkan rincian rata-rata hari kemunculan signal kedua alat analisis. Data tersebut menunjukkan bahwa secara umum MACD memiliki waktu trade, yaitu munculnya pasangan buy dan sell lebih panjang/lama dibanding dengan Stochastic Oscillator. Waktu terpanjang waktu trade pada Stochastic Oscillator tercatat 32 hari, sedangkan pada MACD 122 hari. Hari terpendek, baik Stochastic Oscillator maupun MACD tercatat 2 hari.

Tabel 5: Rata-rata jumlah hari kemunculan trading signal

\begin{tabular}{clrrcccc}
\hline No & Saham & \multicolumn{2}{c}{ Rata-rata hari per trade } & \multicolumn{2}{c}{ STOC } & \multicolumn{2}{c}{ MACD } \\
& & STOC & MACD & $\begin{array}{c}\text { Hari } \\
\text { terpendek }\end{array}$ & $\begin{array}{c}\text { Hari } \\
\text { terpanjang }\end{array}$ & $\begin{array}{c}\text { Hari } \\
\text { terpendek }\end{array}$ & $\begin{array}{c}\text { Hari } \\
\text { terpanjang }\end{array}$ \\
\hline 1 & AALI & 8,63 & 21,52 & 2 & 29 & 7 & 76 \\
2 & ANTM & 10,39 & 23,73 & 4 & 32 & 4 & 65 \\
3 & LPKR & 9,38 & 19,86 & 3 & 25 & 2 & 53 \\
4 & SMGR & 7,28 & 21,85 & 2 & 20 & 6 & 79 \\
5 & TLKM & 7,11 & 24,00 & 2 & 17 & 6 & 63 \\
6 & UNTR & 7,15 & 21,81 & 2 & 15 & 6 & 73 \\
7 & UNVR & 6,68 & 21,96 & 2 & 17 & 5 & 62 \\
8 & ASII & 7,32 & 22,56 & 2 & 15 & 4 & 78 \\
9 & INCO & 6,71 & 32,16 & 2 & 14 & 12 & 122 \\
10 & KLBF & 7,57 & 31,42 & 2 & 20 & 8 & 82 \\
\hline Ant
\end{tabular}

Analisis Hasil Pengujian Hipotesis 1 
Tabel 6: One-Sample T: Stochastic Oscillator Sebelum Fee and Sesudah Fee

\begin{tabular}{llllllll}
\hline \multicolumn{7}{c}{ Test of $\mathbf{~ m u}=\mathbf{0}$ vs not $\mathbf{0}$} \\
\hline Variable & $\mathrm{N}$ & Mean & StDev & SE Mean & $95 \%$ CI & T & P \\
\hline Sebelum Fee & 90 & 5,695 & 5,432 & 0,573 & $(4,557 ; 6,833)$ & 9,95 & 0,000 \\
Sesudah Fee & 90 & 5,172 & 5,395 & 0,569 & $(4,042 ; 6,302)$ & 9,09 & 0,000 \\
Abnormal Return & 90 & 2,95 & 23,65 & 2,49 & $(-2,00 ; 7,91)$ & 1,19 & 0,239 \\
\hline
\end{tabular}

Pengujian pada Stochastic Oscillator berkaitan dengan kemampuannya untuk menghasilkan capital gain sekaligus abnormal return memberikan hasil yang cukup menjanjikan. Dari 90 kelompok transaksi selama 3 tahun, diperoleh ratarata return sebelum biaya transaksi sebesar $5,695 \%$ dengan deviasi sebesar 5,432\%, dan rata-rata 5,172\% dengan deviasi sebesar $5,395 \%$ setelah dipotong biaya transaksi dan pajak. Abnormal return, yaitu return yang sudah diperhitungkan dengan return yang diharapkan, yaitu berupa perubahan indeks JII pada periode yang sama, menghasilkan rata-rata positif sebesar 2,95\%. Rangkuman hasil perhitungan dapat dilihat pada Tabel 6 .

Deviasi yang cukup besar pada abnormal return, yaitu sebesar 23,65\% menunjukkan bahwa ada cukup banyak konvergensi antara perubahan hargaharga saham yang dipilih dengan perubahan indeks JII.

Pengujian pada tingkat signifikansi alpha sebesar 5\%, baik sebelum maupun sesudah biaya dan pajak menghasilkan nilai probabilitas 0,000 , atau lebih kecil dari 0,05. Karena nilai tersebut berada di luar daerah penerimaan hipotesis, maka secara statistik tidak memiliki bukti untuk menerima Ho, atau dengan kata lain Ho ditolak dan Ha diterima. Dengan demikian, maka dapat disimpulkan bahwa Stochastic Oscillator dapat digunakan untuk menghasilkan capital gain bagi investor yang menggunakannya.

Pengujian abnormal return pada tingkat signifikansi alpha sebesar 5\%, baik sebelum maupun sesudah biaya dan pajak menghasilkan nilai probabilitas 0,239 , atau lebih besar dari 0,05. Karena nilai tersebut berada di dalam daerah penerimaan hipo- tesis, maka secara statistik memiliki bukti untuk menerima Ho dan menolak Ha. Dengan demikian, maka dapat disimpulkan bahwa secara statistik adanya abnormal return pada saat menggunakan Stochastic Oscillator tidak dapat dibuktikan.

\section{Analisis Hasil Pengujian Hipotesis 2}

Pengujian pada MACD berkaitan dengan kemampuannya untuk menghasilkan capital gain sekaligus abnormal return memberikan hasil yang cukup menjanjikan. Dari 90 kelompok transaksi selama 3 tahun, diperoleh rata-rata return sebelum biaya transaksi sebesar 6,90\% dengan deviasi sebesar $12,79 \%$, dan rata-rata $6,27 \%$ dengan deviasi sebesar $12,74 \%$ setelah dipotong biaya transaksi dan pajak. Abnormal return, yaitu return yang sudah diperhitungkan dengan return yang diharapkan, yaitu berupa perubahan indeks JII pada periode yang sama, menghasilkan rata-rata positif sebesar $4,06 \%$. Rangkuman hasil perhitungan dapat dilihat pada Tabel 7.

Deviasi yang cukup besar pada abnormal return, yaitu sebesar 24,38\% menunjukkan bahwa ada cukup banyak konvergensi antara perubahan hargaharga saham yang dipilih dengan perubahan indeks JII.

Pengujian pada tingkat signifikansi alpha sebesar 5\%, baik sebelum maupun sesudah biaya dan pajak menghasilkan nilai probabilitas 0,000 , atau lebih kecil dari 0,05. Karena nilai tersebut berada di luar daerah penerimaan hipotesis, maka secara statistik tidak memiliki bukti untuk menerima Ho, atau dengan kata lain Ho ditolak dan $\mathrm{Ha}$ diterima. Dengan demikian, maka dapat disimpulkan bahwa Stochastic Oscillator dapat digunakan untuk 
menghasilkan capital gain bagi investor yang menggunakannya.

Pengujian abnormal return pada tingkat signifikansi alpha sebesar 5\%, baik sebelum maupun sesudah biaya dan pajak menghasilkan nilai probabilitas 0,118, atau lebih besar dari 0,05. Karena nilai tersebut berada di dalam daerah penerimaan hipotesis, maka secara statistik memiliki bukti untuk menerima Ho dan menolak Ha. Dengan demikian, maka dapat disimpulkan bahwa secara statistik adanya abnormal return pada saat menggunakan MACD tidak dapat dibuktikan.

\section{Analisis Hasil Pengujian Hipotesis 3}

Dengan menjumlahkan setiap signal yang muncul, positif ataupun negatif, baik pada Stochastic Oscillator maupun pada MACD, dapat dihitung total return selama 3 tahun (Tabel 8). Hasil pengujian beda rata-rata return antara Stochastic Oscillator dan MACD dapat dilihat pada tabel 9 dan 10 di bawah ini.

Tabel 7: One-Sample T: MACD Sebelum Fee and Sesudah Fee

\begin{tabular}{lccccccc}
\hline \multicolumn{1}{c}{ Test of $\mathbf{~ m u}=\mathbf{0}$ vs not $=\mathbf{0}$} \\
\hline Variable & $\mathbf{N}$ & Mean & StDev & SE Mean & $\mathbf{9 5 \%} \mathbf{C I}$ & $\mathbf{T}$ & $\mathbf{P}$ \\
Sebelum Fee & 90 & 6,90 & 12,79 & 1,35 & $(4,22,9,57)$ & 5,12 & 0,000 \\
Sesudah Fee & 90 & 6,27 & 12,74 & 1,34 & $(3,60,8,94)$ & 4,67 & 0,000 \\
Abnormal Return & 90 & 4,06 & 24,38 & 2,57 & $(-1,05,9,16)$ & 1,58 & 0,118 \\
\hline
\end{tabular}

Tabel 8: Total Return selama 3 tahun (Januari 2008 - Desember 2010)

\begin{tabular}{lcccc}
\hline & $\mathbf{2 0 0 8}$ & $\mathbf{2 0 0 9}$ & $\mathbf{2 0 1 0}$ & Total \\
\hline MACD sebelum Fee & $151,60 \%$ & $271,16 \%$ & $197,97 \%$ & $620,73 \%$ \\
MACD sesudah Fee & $133,07 \%$ & $252,21 \%$ & $179,28 \%$ & $564,55 \%$ \\
STOC sebelum Fee & $232,63 \%$ & $166,65 \%$ & $113,27 \%$ & $512,55 \%$ \\
STOC sesudah Fee & $215,15 \%$ & $151,79 \%$ & $98,52 \%$ & $465,46 \%$ \\
\hline
\end{tabular}

Tabel 9: Two-Sample T-Test and CI: Sebelum Fee, Alat

\begin{tabular}{ccccc}
\hline Alat & $\mathbf{N}$ & Mean & StDev & SE Mean \\
\hline STOC & 90 & 5,69 & 5,43 & 0,57 \\
MACD & 90 & 6,90 & 12,8 & 1,30 \\
\hline
\end{tabular}

Difference $=m u(M A C D)-m u(S T O C)$

Estimate for difference: 1,20

95\% CI for difference: $(-1,69 ; 4,09)$

T-Test of difference $=0$ (vs not $=):$-Value $=0,82 P$-Value $=0,413$ DF $=178$

Both use Pooled StDev $=9,8230$

Tabel 10: Two-Sample T-Test and CI: Sesudah Fee, Alat

\begin{tabular}{ccccc}
\hline Alat & $\mathbf{N}$ & Mean & StDev & SE Mean \\
\hline STOC & 90 & 5,17 & 5,40 & $0, .57$ \\
MACD & 90 & 6,30 & 12,7 & 1,30 \\
\hline
\end{tabular}

Difference $=m u(M A C D)-m u(S T O C)$

Estimate for difference: 1,10

95\% CI for difference: $(-1,78 ; 3,98)$

T-Test of difference $=0$ (vs not $=$ ): $T$-Value $=0,75$ P-Value $=0,451 D F=178$

Both use Pooled StDev $=9,7837$ 
Pada tingkat signifikansi alpha sebesar $5 \%$, baik sebelum maupun sesudah biaya dan pajak menghasilkan nilai probabilitas 0,413 dan 0,451, atau lebih besar dari 0,05 . Karena nilai tersebut berada di dalam daerah penerimaan hipotesis, maka secara statistik memiliki bukti untuk menerima Ho dan menolak Ha. Dengan demikian, maka dapat disimpulkan bahwa tidak ada perbedaan capital gain antara Stochastic Oscillator dengan MACD.

\section{PENUTUP}

Simpulan

Dari hasil pengujian hipotesis didapatkan beberapa kesimpulan sebagai berikut. 1) Penggunaan Stochastic Oscillator secara statistik signifikan dapat menghasilkan capital gain bagi investor, khususnya di saham-saham yang masuk dalam indeks JII. Sebaliknya, penelitian ini tidak dapat membuktikan bahwa penggunaan Stochastic Oscillator secara signifikan dapat menghasilkan abnormal return. 2) Penggunaan MACD secara statistik signifikan dapat menghasilkan capital gain bagi investor, khususnya di saham-saham yang masuk dalam indeks JII. Sebaliknya, penelitian ini tidak dapat membuktikan bahwa penggunaan MACD secara signifikan dapat menghasilkan abnormal return. 3) Tidak terbukti adanya perbedaan capital gain pada Stochastic Oscillator dengan MACD. 4) Keberhasilan Stochastic Oscillator dan MACD mendapatkan capital gain menunjukkan bahwa pasar modal Indonesia tidak sepenuhnya mencerminkan dukungan terhadap Efficient Market Hypothesis (EMH). Sungguhpun demikian ketidakberhasilan penelitian ini untuk membuktikan adanya abnormal return pada penggunaan analisis teknikal menunjukkan bahwa pasar modal
Indonesia sudah mulai menunjukkan pembentukan efisiensi pasar.

\section{Saran}

Menyadari bahwa penelitian ini masih jauh dari sempurna, disarankan beberapa hal berikut. 1) Kemunculan sinyal buy dan sell pada kedua alat analisis, yaitu Stochastic Oscillator dan MACD sangat tergantung kepada penentuan parameter masing-masing. Pada Stochastic Oscillator, penentuan besaran jumlah periode (n) untuk menghitung \%K. Menurut Syamsir (2008), pemilihan jumlah periode untuk $\% \mathrm{~K}$ akan sangat bervariasi dari satu pengguna ke pengguna lain, atau dari satu saham ke saham lain, tergantung pada tingkat volatilitas dari saham yang bersangkutan. Pada MACD penentuan besaran XMA1 dan XMA2 akan menentukan pola grafik. Dengan melakukan trial and error, para chartists dapat melakukan optimalisasi dengan cara simulasi mengubah-ubah parameter sehingga dapat ditemukan kombinasi parameter yang paling besar menghasilkan return. Sehubungan dengan hal tersebut, untuk menyempurnakan penelitian disarankan untuk: melakukan simulasi trial and error pada Stochastic Oscillator untuk menemukan besaran jumlah periode yang menghasilkan return optimal sebelum hasilnya diuji kembali. Melakukan simulasi trial and error pada MACD untuk menemukan XMA1 dan XMA2 yang dapat menghasilkan return optimal sebelum hasilnya diuji kembali. 2) Kepada para investor sekuritas, terutama yang berorientasi pada saham-saham syariah disarankan mempertimbangkan untuk menggunakan alat-alat analisis teknikal sebagai salah satu alat bantu pembuatan keputusan investasinya.

\section{DAFTAR PUSTAKA}

Achelis, Steven, (2003), Technical Analysis From A to Z, Equis International, Salt Lake City

Ang, Robbert, (1997), Buku Pintar Pasar Modal Indonesia, Mediasoft Indonesia 
Brock, W., J. Lakonishok, and B. LeBaron, (1992), “Simple Technical Trading Rules and The Stochastic Properties of Stock Returns", Journal of Finance 48 (5), 1731-1764

Caginalp, Gundus and Balenivitch, Donald, (2003), “A Theoritical Foundation of Technical Analysis", Journal of Technical Analysis, Winter-Spring, 5-21

Eric, Dejan, Andjelic, Goran, and Srdjan Redzepagic, (2009), “Application of MACD and RVI Indicators as Function of Investment Strategy Optimization on the Financial Market", Zb. rad. Ekon. fak. Rij., vol. 27• sv. 1・171-196

Fama, Eugene F., (1970), “Efficient Capital Markets: Review of Theory and Empirical Work", Journal of Finance, Vol. 25 Issue 2

Kim, Jae H., Shamsuddin, Abul , (2007), “Are Asian Stock Markets Efficient? Evidence from New Multiple Variance Ratio Tests", Journal of Empirical Finance 15, 518-532

Keith S.K. Lam, H. F. Yeung and William Cheung, (2007), "The Profitability of Simple Technical Trading Strategies: The Case of Hong Kong", http://ssrn.com/abstract = 1008740.

Lento, Camillo, (2008), “A Combined Signal Approach To Technical Analysis On The S\&P 500", http://papers.ssrn.com/sol3/papers.cfm?abstract_id $=1113622$.

Marshall, Cahan, and Cahan, (2010), "Technical Analysis around the World", http://ssrn.com/abstract $=1181367$.

Meissner, Alex, and Nolte, (2002), "A Refined MACD Indicator-Evidence Against the Random Walk Hypothesis?", http://momentum.technical analysis .org.uk/MeAN.pdf

Murphy, John J., (1999), Technical Analysis of The Financial Markets, New York Institute of Finance.

Naha, Aniruddha and Zaidi, Zaheer Abbas, (2004), "Examination of Yields and Spreads of Indian Debt Securities through Technical Analysis Tools", http://papers.ssrn.com/sol3/papers.cfm?abstract_id=ssrn-id501722

Park, Cheol-Ho and Irwin, Scott H., (2004), “The Profitability of Technical Analysis: A Review", AgMAS Project Research Report, 2004-04

Pring, Martin J., (2005), Martin Pring on Price Pattern, McGraw-Hill.

Reuters, (1999), An Introduction to Technical Analysis, John Wiley \& Sons Inc.

Rubio, Fernando, (2003), "Some Technical Analysis On The Stock Market: Spain and USA", http://papers.ssrn.com/sol3/papers.cfm?abstract_id $=507722$.

Sundhar, Shyam and Kakani, Ram Kumar, (2004), "Profiting From Technical Analysis in India Equity Market: Using Moving Averages", Working Paper 06-02, XLRI Jamshedpur, School of Management, India, http://papers.ssrn.com/sol3/ papers.cfm?abstract_id $=889515$.

Syamsir, Hendra, (2008), Solusi Investasi di Bursa Saham Indonesia, Elex Media Komputindo.

Tandelilin, Eduardus, (2010), Portfolio dan Investasi, Teori dan Aplikasi, Edisi Pertama, Kanisius.

Thorp, A, Wayne, (2000), "The MACD: A Combo of Indicators For The Best of Both World", AAII Journal, January, 30-34. 
Wong, Wing-Keung, Manzur, Meher, and Chew, Boon-Kiat, (2002), “How Rewarding Is Technical Analysis? Evidence From Singapore Stock Market", Working Paper No. 0216, Department of Economics, National University of Singapore, http://www.fas.nus.edu.sg/ecs/ pub/wp/wp0216.pdf.

Wong, Wing-Keung, Du, Jun and Chong, Terence Tai-Leung, (2005), “Do the Technical Indicators Reward Chartists? A Study on The Stock Markets of China, Hongkong and Taiwan", http://net2.hkbu.edu.hk/ ied/publications/fdp/FDP200501.pdf. 